\title{
CROP ROTATION WITH BRASSICA REDUCES DISEASE IN POTATO CROPS
}

\author{
A.T. MARSH, L-H. CHEAH and D.I. HEDDERLEY \\ Plant \& Food Research, Private Bag 11600, Palmerston North, New Zealand \\ Corresponding author: cheahl@crop.cri.nz
}

A long-term trial (5 years) was conducted at a commercial property with a history of high incidence and severity of soilborne diseases. Five rotational crops (potato, pasture, Brassica, cereal and squash) were tested for their effects on soilborne diseases on potatoes. These crops were grown in plots for about 4 months and then ploughed back into the soil 30 days prior to planting potatoes. Soil applications of metalaxyl fungicide were used as a standard (control) treatment. After four growing seasons there was evidence that rotational treatments, particularly Treatment 2 (cereal + Brassica crop), reduced the amount of diseased potatoes, and the proportion of the crop that was diseased compared with the control treatment (potatoes and pasture with or without metalaxyl) $(\mathrm{P}=0.046$ and 0.016 respectively). Combining these results with harvest data from previous years, there was no significant difference between the treatments in terms of yield per plant. However, there did appear to be a marginal difference $(\mathrm{P}=0.1)$ in the proportion of the crop that was diseased, with Treatment 4 (without Brassica crop) being higher than other treatments that had Brassica crops. In previous work, soil analysis had shown that a rotation with Brassica crops reduced the level of Phytophthora and other species of soilborne fungi compared with the same rotation without Brassica crops.

\section{EFFECT OF HOT WATER DIP TREATMENT ON SEEDBORNE PATHOGENS AND GERMINATION OF CARROT SEEDS}

\author{
L-H. CHEAH, A.T. MARSH AND D.I. HEDDERLEY \\ Plant \& Food Research, Private Bag 11600, Palmerston North, New Zealand \\ Corresponding author: cheahl@crop.cri.nz
}

The effect of hot water treatment of carrot seeds on seedborne pathogens (Alternaria and Fusarium spp) and seed germination was studied. Carrot seeds (no fungicide) were dipped in water at $50^{\circ} \mathrm{C}$ or $52^{\circ} \mathrm{C}$ for 10,20 or $30 \mathrm{~min}$ and plated on potato dextrose agar to assess pathogen growth. Treated seeds were sown in cell trays to assess germination in a glasshouse. The weight of the germinated seedlings was also recorded. All hot water treatments significantly $(\mathrm{P}<0.001)$ reduced the number of seeds bearing pathogens compared with the control (tap water). Treatment at $50^{\circ} \mathrm{C}$ for $30 \mathrm{~min}$ and $52^{\circ} \mathrm{C}$ for 10 and $30 \mathrm{~min}$ gave almost complete kill of seedborne pathogens. For Alternaria, treatment at $52^{\circ} \mathrm{C}$ gave fewer seeds with pathogens than treatment at $50^{\circ} \mathrm{C}(\mathrm{P}<0.001)$, whereas for Fusarium $50^{\circ} \mathrm{C}$ gave fewer seeds with pathogens than $52^{\circ} \mathrm{C}(\mathrm{P}<0.001)$. Treatment time did not affect the proportion of seeds bearing Fusarium, but longer treatments reduced the numbers with Alternaria. Treated seeds were more likely to germinate than control seeds (treated $=43-64 \%$; control $=23 \% ; \mathrm{P}<0.001$ ). There were only marginal differences in germination between treatment times: at $50^{\circ} \mathrm{C}$, treatment time did not affect germination, whereas at $52^{\circ} \mathrm{C}$ longer treatment reduced germination. All hot water dip treatments (except $52^{\circ} \mathrm{C}$ for $30 \mathrm{~min}$ ) gave increased seedling weights over the control. 